\title{
STRUCTURAL DESIGN OF TOUGHENED GLASS FACADE USINGEURO CODE
}

\author{
Rao G.S ${ }^{1}$. K. Rajasekhar ${ }^{2}$ \\ ${ }^{1}$ Research Scholar, Department of Civil Engineering, Andhra University, gsrao.civil@gmail.com \\ ${ }^{2}$ Assistant Professor, Department of Civil Engineering, Andhra University, krsekhar08@gmail.com
}

\begin{abstract}
Synopsis
Glass panel usage was evolved from non-structural usage as windows to structural applications as facades supporting on metal framing. Glass panels now designed as self-supporting system to get fully transparent structures. Glass structures are found in extensive shapes from flat panel to complex tubes, corrugated glass. Various types of glass materialsdetails are listed. Available analytical procedures to evaluate the strength of glass facades include -linear, non-linear analysis is summarized. An overview of design rules from Indian draft code and Euro Code was summarized. Comparative study of toughened glass panel strength with Indian draft codeand Euro code provisions was performed for the suitability and limitations for usage of tempered glass in different scenarios.
\end{abstract}

Keywords: Glass structures, toughened glass, design codes, Indian draft code, Euro code

\section{INTRODUCTION}

Glass panel usage evolved fromolden days, mainly asvessels, beads, windows and in jewelry.Even though most of the glass wares/windows in historical buildings are used as non-structural component, there was an experimental science behind the large sizes of vessels/boxes/window spans used in construction of churches and large buildings ${ }^{1}$. In the modern era we can find glass usage of glass elements both in non-structural and structural applications. Building construction, automobile, solar - industries are more concerned with structural integrity of glass elements with other framing members. Window glasses are found as framed as well as self supported. Self supporting ${ }^{2}$ facades provide lighter structural loads in addition to aesthetic and fully transparent view of building.

Different usage of glass panes as membrane (enclosing or barrier) and non-membrane element was explained by Christopher ${ }^{3}$. The non-membrane structural glass supports the dead loads of the enclosure, and transmits the live loads to the main building structure in the form of glass fins, mullions, beams, and masonry walls. Apart from flat panels other shapes including curved, doubly curved, tubular glass sections are manufactured forserving variety of applications ${ }^{4}$.

Literature shows that glass structures are now a day's used in all places of buildings such as façade, staircase, beam, column and roof. Connections for supporting glass elements includes such as continuous support frame with setting blocks and silicone sealants, clamps and friction grip connections. Based on manufacturing process and other properties glasses are classified as normal or annealed, toughened or tempered glass, heat-strengthened glass, reflective glass, insulating glass. Common structural properties of these glasses are shown in table-1.

General methods of analysis of glass structures are linear analysis, nonlinear analysis and finite element method. Experimental strengths or their empirical relations are mandatory for accounting the probability of material strength in different manufacturing processes. Since glass is weak in tension and post-breakage strength is not utilized, linear plate theory gives conservative values, however in case of excessive deflections ( $\mathrm{w}>\mathrm{T}$ or $\mathrm{T} / 2$, $\mathrm{w}$-maximum deflection, T-thickness of glass), large deflection theory was used for calculating bending stresses and deflection.

\section{DESIGN OF TOUGHENED GLASS ELEMENT}

\section{1toughened Glass}

Toughened or tempered glass is a strong glass which is heated to a uniform temperature of approximately $650^{\circ} \mathrm{C}$ and rapidly cooled to induce compressive force of 770 $\mathrm{kg} / \mathrm{cm}^{2}$ to $1462 \mathrm{~kg} / \mathrm{cm}^{2}$ on the surfaces and edge compression of the order of $680 \mathrm{~kg} / \mathrm{cm}^{2}$. Concept of tempering (thermal treatment) is to produce residual tensile stresses in the core of the glass and compressive stresses on and near the surfaces. The mid thickness portion of glass does not contain flaws and therefore offers good resistance to tensile stress. Flaws on glass surface will grow if they are subjected to resultant tensile stress. Tensile stresses on surface due to applied loads are smaller than residual compressive stress; hence crack growth can be arrested (Fig.1).

These glasses are strong to resist impact and fire loads. Tempering imparts strength from the compressed surfaces. On impact these glasses will break into number of small particles. Main application of these glasses are where safety and strength are important as - curtain walls of high rise buildings, escalator side plates, airports and sport 
complexes. The main limitation of these types of glasses is any cutting or drilling process is to be performed before the heat treatment; therefore on site fabrication changes are not possible.

\subsection{Design Methodology of Indian Draft Code5for}

\section{Toughened Glass Element}

In addition to the calculation procedures given below, following rules will apply for design

- Procedures applicable only forwind induced loads

- Procedures are applicable to rectangular shaped panel only, with aspect ratio more than 1.5.

- Maximum allowable area of glass panels is $15 \mathrm{~m}^{2}$.

- Maximum span of window glass is $4 \mathrm{~m}$

- Maximum allowed deflection for single glazing = Span $/ 125$ and for double glazing = Span $/ 175$

\subsubsection{Thickness (T) Of Rectangular Panes}

\section{Supported On All Four Edges Iscalculated Using}

\section{Following Empirical Equation-1a And 1b}

Check for maximum allowable span from given figure or tables

$$
\begin{array}{llll}
\left(\mathrm{P}_{\text {net }} / \mathrm{P}_{\mathrm{f}}\right) * \mathrm{~A}=200 * \mathrm{~T}^{\mathrm{k}} & \text { (for } \mathrm{T} \leq & 6 \mathrm{~mm}) \\
. .(1 \mathrm{a}) & & \text { (for } \mathrm{T}>6 & \mathrm{~mm}) \\
\left(\mathrm{P}_{\text {net }} / \mathrm{P}_{\mathrm{f}}\right) * \mathrm{~A}=200 * \mathrm{~T}^{\mathrm{k}}+1900 & \\
\quad . .(1 \mathrm{~b}) & &
\end{array}
$$

Where, $\mathrm{P}_{\text {net }}=$ Net design wind pressure $\left(\mathrm{N} / \mathrm{m}^{2}\right)$ calculate using IS875-1987, Part- $3^{6}$,

$\mathrm{P}_{\mathrm{f}}=$ strength factor $=2.5$ for tempered/toughened glass type

$\mathrm{A}=$ Area of glass panel $\left(\mathrm{m}^{2}\right)$

$\mathrm{T}=$ Standard nominalthickness of glass $(\mathrm{mm})$

$\mathrm{k}=$ Constant from the table 2 .

\subsubsection{Thickness (T) Of Rectangular Panes}

\section{Supported On Two Opposite Edges Is Calculated}

\section{Using Empirical Equation-2a And 2b}

Check for maximum allowable span (b) from given figure or tables

$\mathrm{b}=(3.2688 \times \mathrm{T}) / \sqrt{ }\left(\mathrm{P}_{\text {net }} / \mathrm{P}_{\mathrm{f}}\right) \quad($ for $\mathrm{T} \leq 6 \mathrm{~mm})$

$\mathrm{b}=2.9069 \times \mathrm{T} / \sqrt{ }\left(\mathrm{P}_{\text {net }} / \mathrm{P}_{\mathrm{f}}\right) \quad($ for $\mathrm{T} \geq 6 \mathrm{~mm})$

Where,

$\mathrm{b}=$ span, in $\mathrm{m}$

Calculate for maximum deflection at centre of glass using the procedure given in annexure B of draft Code, as shown below

Deflection $(\mathrm{w})=\mathrm{t} * \mathrm{e}_{0}^{\left(\mathrm{r}+\mathrm{r}_{1} * \mathrm{X}+\mathrm{r}_{2} * \mathrm{X} * \mathrm{X}\right)}$

$X=\operatorname{Ln}\left(\operatorname{Ln}\left(q\left(a^{*} b\right) 2 / E t^{4}\right)\right)$.

$\mathrm{r}_{0}=0.553-3.83(\mathrm{a} / \mathrm{b})+1.11(\mathrm{a} / \mathrm{b})^{2}-0.0969(\mathrm{a} / \mathrm{b})^{3}$.

$\mathrm{r}_{1}=-2.29+5.53(\mathrm{a} / \mathrm{b})-2.17(\mathrm{a} / \mathrm{b}) 2+0.2067(\mathrm{a} / \mathrm{b})^{3}$

$\mathrm{r}_{2}=1.485-1.908(\mathrm{a} / \mathrm{b})+0.815(\mathrm{a} / \mathrm{b})^{2}-0.0822(\mathrm{a} / \mathrm{b})^{3}$.
Where,

$\mathrm{E}=$ Young's modulus of glass

$q=$ Net pressure on the pane $\left(\mathrm{N} / \mathrm{m}^{2}\right)$

$\mathrm{a}=$ Longer dimension $(\mathrm{mm})$

$\mathrm{b}=$ Shorter dimension $(\mathrm{mm})$

$\mathrm{t}=$ Thickness of the glass pane calculated.

\subsection{Design Methodology Of Euro Code6 For}

\section{Toughened Glass Element}

Euro code ${ }^{6,7}$ design method of glass facade is based on partial factor for including any material defects such as flaws, inclusions variation of strength changes in manufacturing process. Procedure also includes combination factors for different permanent loads such as dead load and live load and other climatic loads. Design procedure of glass elements to uniformly distributed load like wind forces with combination of other loads are given in detail for different shapes including rectangle, triangle and other geometries. Maximum stress $\left(\sigma_{\max }\right)$, effective stress $\left(\sigma_{\text {eff }}\right)$,maximum deflection $\left(\mathrm{w}_{\max }\right)$ equations are given separately for each case in prEn13474-part- $2^{7}$. Two different set of coefficients $\left(\mathrm{k}_{1}, \mathrm{k}_{2}, \mathrm{k}_{4}\right.$, for linear theory and non-linear theory) using were given for determining the stresses and deflections. Euro code $^{7}$ suggests that linear theory coefficients can be used when deflections are small, i.e. less than the half of thickness of glass panel $\left(\mathrm{w}_{\max }<\mathrm{t} / 2\right)$.

An overview of the procedure to be followed in design of rectangular glass facade supported on all four edges is given below.

[1]. Choose type of glass as thermally toughened glass

[2]. Find partial factors for variation in strength of material, $\gamma_{\mathrm{m}}(1.8$ for ultimate limit state and 1.0 for serviceability limit state) and $\gamma_{\mathrm{v}}(2.3$ for ultimate limit state and 1.5 for serviceability limit state)compressive surface forces resulting from inhomogeneity of material from prEn13474-part-1 ${ }^{6}$.

[3]. Find design load for ultimate limit state and serviceability limit state using combination factors given,fromprEn13474-part- $2^{7}$ using equations $4 \mathrm{a}$ and $4 \mathrm{~b}$,

[4]. $F_{d}=\sum \gamma_{G} G+\gamma_{Q} Q$, for ultimate limit state $\left(\gamma_{Q}=1.5\right) \ldots$ (4a)

[5]. $\quad F_{d}=\sum \gamma_{G} G+\gamma_{Q} Q$, forand serviceability limit state $\left(\gamma_{Q}\right.$ $=1.0) \ldots(4 \mathrm{~b})$

[6]. $\mathrm{G}=0$, as only wind load $(\mathrm{Q})$ is consideredin present calculations

[7]. Find normalized load, $\quad p^{*}=\frac{b^{4}}{t^{4}} \frac{F_{d}}{E} \ldots$

[8]. Find stress and deflections using equations5, 6, 7 as given for rectangular glass panes supported on four edges

Maximum tensile stress, $\quad \sigma_{\max }=k_{1} \frac{b^{2}}{t^{2}} F_{d} \quad \ldots$

Effective stress, $\quad \sigma_{\max }=k_{2} \frac{b^{2}}{t^{2}} F_{d} \quad \ldots$

Defection, $\quad w_{\max }=k_{4} \frac{b^{4}}{t^{3}} \frac{F_{d}}{E}$

Where $b=$ Shorter dimension of panel

$\mathrm{k}_{1}, \mathrm{k}_{2}, \mathrm{k}_{4}$ are Coefficients given in tables for normalized load 
( $\mathrm{q}^{*}$ )with reference to different aspect ratios

a) Find allowable stress $\left(f_{g, \mathrm{~d}}\right)$ for pre-stressed i.e toughened glass element using equation 9

b)

$f_{g, d}=\left\lfloor\frac{f_{b, k}-f_{g, k}}{\gamma_{m}}-k_{\text {mod }} \frac{f_{g, k}}{\gamma_{m} k_{A}}\right\rfloor \gamma_{n} \ldots$

Where

$\gamma_{\mathrm{n}}=1.0$,(common to many nations) National partial factor from prEn13474-part- $1^{6}$

$\mathrm{f}_{\mathrm{b}, \mathrm{k}}=120 \mathrm{~N} / \mathrm{mm}^{2}$, Characteristic fracture strength of borosilicate pre-stressed (toughened glass) from prEn13474part- ${ }^{6}$

$\mathrm{f}_{\mathrm{g}, \mathrm{k}}=45 \mathrm{~N} / \mathrm{mm}^{2}$, General characteristic inherent strength of borosilicate (toughened glass) from prEn13474-part- $1^{6}$

$\mathrm{f}_{\mathrm{b}, \mathrm{k}}-\mathrm{f}_{\mathrm{g}, \mathrm{k}}=$ Contribution of residual stress to failure strength

$\mathrm{k}_{\text {mod }}=0.72$, Modification factor for accounting the duration of load

$\mathrm{k}_{\mathrm{A}}=\mathrm{A}^{0.04}$,Size factor determined from area of glass panel

c) Check whether the stresses and deflections are in allowable values, deflectioncriteria must also satisfy correspondingnational code provisions.

\section{MODEL CALCULATIONS OF FAÇADE}

\section{DESIGN}

\subsection{Model Calculation Using Indian Draft Code}

As a part of this paper, model calculations were performed to find the thicknesses and deflections of glass façade of multistory commercial complex of $18 \mathrm{mx} 24 \mathrm{~m}$ plan dimensions and height of $60 \mathrm{~m}$ situated in Visakhapatnam location.Separatecalculations performed for wind speeds corresponding to normal basic wind speed $(50 \mathrm{~m} / \mathrm{s})$ given in code $^{8}$ and Hud-Hud cyclone wind speed of $225 \mathrm{Km} / \mathrm{hr}(62.5$ $\mathrm{m} / \mathrm{s}$ ). Average story height of $4 \mathrm{~m}$ and frames are spaced $6 \mathrm{~m}$ $\mathrm{c} / \mathrm{c}$ in both directions was considered.

\section{Design}

Discontinuous façade between each floor slab with single pane toughened glass of $1.5 \mathrm{~m}$ width $\times 3.6 \mathrm{~m}$ height was assumed for construction.

Therefore corresponding area of glass pane, $\mathrm{A}=1.5 \times 3.6=$ $5.4 \mathrm{~m}^{2}$

\section{Wind Loading Calculations Are Performed With}

\section{Procedure Given Below}

The net design wind pressure $\left(\mathrm{P}_{\text {net }}\right)$ calculated using procedure of IS $875-1987$, Part- $3^{8}$ was shown along with other parameters.

Aspect ratio of building $=\mathrm{h} / \mathrm{w}=60 / 18=3.3$,

Risk coefficient, $\mathrm{k}_{1}=1.0$, for terrain category- 1 for sea side facing window/façade glazing, structure of type class-A, Mean probable life of 50 years.

Terrain Factor, $\mathrm{k}_{2}=1.05,1.09,1.12,1.15,1.20$ at 10, 15, 20, 30,50 to $60 \mathrm{~m}$ heightsrespectively.

By interpolationk $k_{2}$ at different storey height was calculated and shown in table-3,

Topography Factor, $\mathrm{k}_{3}=1.0$

Force coefficient, $\mathrm{C}_{\mathrm{p}}=1.7$ foran assumed permeability in the range of $5 \%-20 \%$ openings

Basic wind pressure, $\mathrm{p}_{\mathrm{z}}=0.6 \mathrm{v}_{\mathrm{z}}^{2} \ldots$

$\mathrm{v}_{\mathrm{Z}}=\mathrm{v}_{\mathrm{b}} \cdot \mathrm{k}_{1} \cdot \mathrm{k}_{2} \cdot \mathrm{k}_{3} \ldots$

Where,

$\mathrm{v}_{\mathrm{b}}$ - basic wind speed based on visakhapatnam location from- IS 875 Part- $3^{8}=50 \mathrm{~m} / \mathrm{s}$

$\mathrm{p}_{\mathrm{z}}$ - basicwind pressure $\mathrm{N} / \mathrm{m}^{2}$ at height $\mathrm{H}$

$\mathrm{P}_{\text {net }}{ }^{-}$design wind pressures on each facade element at corresponding height $=\mathrm{p}_{\mathrm{z}} . \mathrm{C}_{\mathrm{p}} \ldots$

Calculatedthickness required and corresponding deflection are shown in table-3 and table-4

\subsection{Model Calculation Using Euro Code6, 7}

Using the above mentioned Euro code procedure for design of rectangular façade supported on all four edges, calculationswere made for same building example taken for Indian draft Code comparison.Same wind loads are generated using Indian standard IS 875-1987, Part-3 $3^{6}$ was used. Details of calculationsincluding maximum stress, effective stress, allowable stress, maximum deflections are given in table- 5 and table- 6

\section{CONCLUSIONS}

For most of the heights two design procedures Indian draft code and Euro codegivesconservative design.There was a difference in calculated deflections; this is due to considering separate partial factors for material strength, residual stresses and manufacturing process in Euro code, where as in Indian Draft code procedure a single safety factor was used. For higher design loads Euro code prediction is unconservative comparative to Indian draft code, therefore next higher thickness of the glass panel to be selected. Deflection calculation method of Indian draft code was same as ASTM E-1300-2004 9. The effective stresses are on conservative side for higher thickness. This shows that there was a large need to study the different code provisions for creating a commoncode for glass design.

\section{REFERENCES}

[1]. Website: https://en.wikipedia.org/wiki/History_of_glass, date.30-10-2015

[2]. Jan W., "Glass Structures - Design and Construction of Self-supporting Skins”,Birkhäuser Verlag AG, Berlin, 2007

[3]. Christopher P. J., "The use of non-membrane structural glass-A Primer for Architects and Designer", Skidmore, Owings \& Merrill LLP, New York, 2014

[4]. Website: https://www.pilkington.com, date.30-10-2015

[5]. CED 13(7885)WC, "Draft code -Code of practice for use of glass in buildings, Part-3", Bureau of Indian Standards ,Doc no., 2012

[6]. prEN 13474-1:1999,“Glass in building - Design ofglass panes - Part 1: General basis of design". CEN, European Standards, 1999

[7]. prEN 13474-2:2000. Glass in building - Design ofglass panes - Part 2: Design for uniformly 
distributedload. CEN,European Standards, 2000

[8]. IS 875-1987, "Code of practice for design loads for buildings and structures, Part-3, Wind loads", Bureau of Indian Standards, 1989.

[9]. ASTM E 1300-04, "Standard practice for determining loads resistance of glass in buildings", American Society for Testing Materials, 2004.

[10]. Sedlacek, G. Blank, K., Laufs, W. and Gusgen, "Journal of GlasimKonstruktivenIngenieurbau”, Ernst \&Sohn, Berlin, 1999.

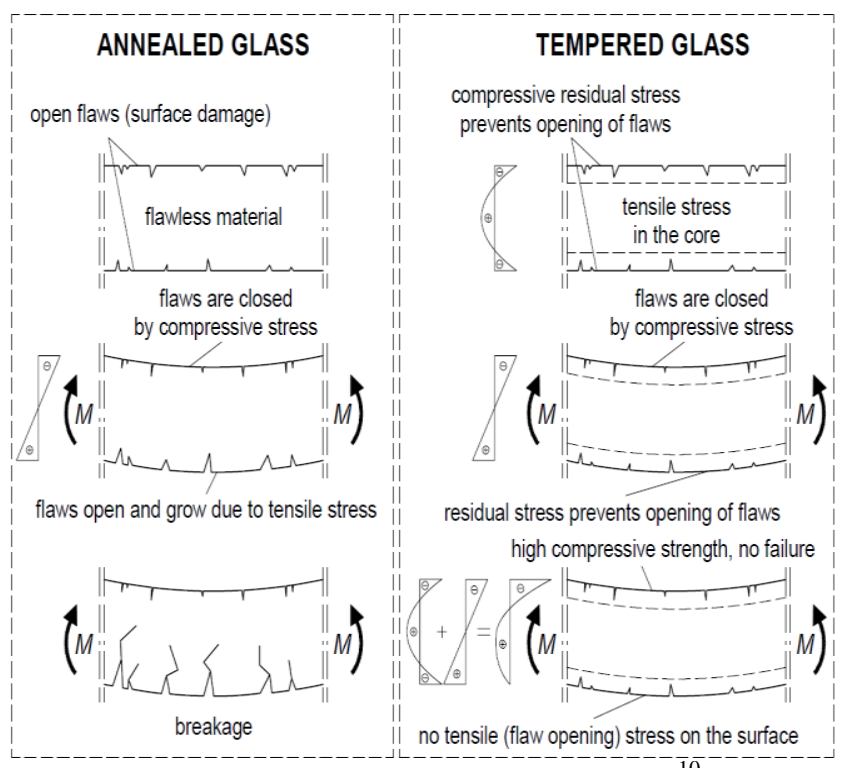

Figure-1 Principle of glass Tempering ${ }^{10}$

Table-1 Typical structural properties for different types of glass

\begin{tabular}{|c|c|c|c|}
\hline Property & $\begin{array}{l}\text { Anneal } \\
\text { ed } \\
\text { Glass }\end{array}$ & $\begin{array}{l}\text { Tempered or } \\
\text { toughened } \\
\text { glass }\end{array}$ & $\begin{array}{l}\text { Lami } \\
\text { nated } \\
\text { glass }\end{array}$ \\
\hline $\begin{array}{ll}\begin{array}{l}\text { Tensile } \\
\left(\mathrm{N} / \mathrm{mm}^{2}\right)\end{array} & \text { strength } \\
\end{array}$ & 40 & $120-200$ & 32 \\
\hline Thickness (mm) & $2-19$ & 42082 & $\begin{array}{l}4.38- \\
20.76 \\
\end{array}$ \\
\hline Density $\left(\mathrm{g} / \mathrm{cm}^{3}\right)$ & $\begin{array}{l}2.42- \\
2.52\end{array}$ & $2.42-2.52$ & $\begin{array}{l}2.42 \\
2.52\end{array}$ \\
\hline $\begin{array}{l}\text { Modulus of } \\
\text { elasticity (GPa) }\end{array}$ & 70 & 70 & 70 \\
\hline $\begin{array}{l}\text { Coefficient of } \\
\text { linear expansion } \\
(\mathrm{m} / \mathrm{m} \mathrm{K})\end{array}$ & $9 \times 10-6$ & $9 \times 10-6$ & $\begin{array}{l}9 \times 10- \\
6\end{array}$ \\
\hline $\begin{array}{l}\text { Compressive } \\
\text { strength }\end{array}$ & 1000 & 1000 & 1000 \\
\hline Normal sizes (mm) & $\begin{array}{l}2440 x \\
3660\end{array}$ & $2440 \times 3660$ & $\begin{array}{l}2000 \\
x \\
3210 \\
\end{array}$ \\
\hline
\end{tabular}

Table-2 k value for the corresponding Standard Normal Thickness

\begin{tabular}{|c|c|c|c|c|c|c|c|c|c|c|}
\hline $\mathrm{T}$ & $\begin{array}{l}3 \\
\mathrm{~m} \\
\mathrm{~m}\end{array}$ & $\begin{array}{l}4 \\
\mathrm{~m} \\
\mathrm{~m}\end{array}$ & $\begin{array}{l}5 \\
\mathrm{~m} \\
\mathrm{~m}\end{array}$ & $\begin{array}{l}6 \\
\mathrm{~m} \\
\mathrm{~m}\end{array}$ & $\begin{array}{l}8 \\
\mathrm{~m} \\
\mathrm{~m}\end{array}$ & $\begin{array}{l}10 \\
\mathrm{~m} \\
\mathrm{~m}\end{array}$ & $\begin{array}{l}12 \\
\mathrm{~m} \\
\mathrm{~m}\end{array}$ & $\begin{array}{l}15 \\
\mathrm{~m} \\
\mathrm{~m}\end{array}$ & $\begin{array}{l}19 \\
\mathrm{~m} \\
\mathrm{~m}\end{array}$ & $\begin{array}{l}25 \\
\mathrm{~m} \\
\mathrm{~m}\end{array}$ \\
\hline & 1. & 1. & 1. & 1. & & & & & & \\
\hline $\mathrm{k}$ & $\begin{array}{l}68 \\
3\end{array}$ & $\begin{array}{l}73 \\
2\end{array}$ & $\begin{array}{l}75 \\
3\end{array}$ & $\begin{array}{l}76 \\
5\end{array}$ & $\begin{array}{l}1 . \\
57\end{array}$ & $\begin{array}{l}1.5 \\
78\end{array}$ & $\begin{array}{l}1.5 \\
83\end{array}$ & $\begin{array}{l}1.5 \\
79\end{array}$ & $\begin{array}{l}1.5 \\
69\end{array}$ & $\begin{array}{l}1.5 \\
69\end{array}$ \\
\hline
\end{tabular}

Table-3 Design thicknesses and deflections of glass façade with different floor heights of building for basic wind speed of $50 \mathrm{~m} / \mathrm{s}$ using Indian Draft Code

\begin{tabular}{|l|l|l|l|l|l|}
\hline Height & $\mathbf{k}_{\mathbf{2}}$ & $\mathbf{P}_{\text {net }} / \mathbf{P}_{\mathbf{f}}$ & Thickness & $\mathbf{w}$ - actual & $\mathbf{w - a l l o w a b l e}$ \\
\hline $\mathbf{m}$ & & $\mathbf{N} / \mathbf{m}^{\mathbf{2}}$ & $\mathbf{m m}$ & $\mathbf{m m}$ & $\mathbf{m m}(\mathbf{L} / \mathbf{1 2 5})$ \\
\hline up to 8 & 1.05 & 1125 & 8 & 16.5 & 28.8 \\
\hline 12 & 1.07 & 1168 & 8 & 17.0 & 28.8 \\
\hline 16 & 1.10 & 1234 & 8 & 17.7 & 28.8 \\
\hline 20 & 1.12 & 1279 & 10 & 11.3 & 28.8 \\
\hline 24 & 1.13 & 1302 & 10 & 11.5 & 28.8 \\
\hline 28 & 1.14 & 1326 & 10 & 11.6 & 28.8 \\
\hline 32 & 1.17 & 1396 & 10 & 12.2 & 28.8 \\
\hline 36 & 1.18 & 1420 & 10 & 12.3 & 28.8 \\
\hline 40 & 1.18 & 1420 & 10 & 12.3 & 28.8 \\
\hline 44 & 1.19 & 1444 & 10 & 12.5 & 28.8 \\
\hline 48 & 1.20 & 1469 & 10 & 12.7 & 28.8 \\
\hline 52 & 1.20 & 1469 & 10 & 12.7 & 28.8 \\
\hline 56 & 1.20 & 1469 & 10 & 12.7 & 28.8 \\
\hline 60 & 1.20 & 1469 & 10 & 12.7 & 28.8 \\
\hline
\end{tabular}


Table-4 Design thicknesses and deflections of glass façade with different floor heights of building for Hud-Hud cyclone wind

\begin{tabular}{|l|l|l|l|l|}
\hline Height & $\mathbf{P}_{\text {net }} / \mathbf{P}_{\mathbf{f}}$ & Thickness & w- actual & w-allowable \\
\hline $\mathbf{m}$ & $\mathbf{N} / \mathbf{m}_{\mathbf{2}}$ & $\mathbf{m m}$ & $\mathbf{m m}$ & $\mathbf{m m}(\mathbf{L} / \mathbf{1 2 5})$ \\
\hline up to 8 & 1757.109 & 12 & 9.4 & 28.8 \\
\hline 12 & 1824.684 & 12 & 9.8 & 28.8 \\
\hline 16 & 1928.438 & 12 & 10.3 & 28.8 \\
\hline 20 & 1999.2 & 12 & 10.6 & 28.8 \\
\hline 24 & 2035.059 & 12 & 10.8 & 28.8 \\
\hline 28 & 2071.238 & 12 & 10.9 & 28.8 \\
\hline 32 & 2181.684 & 12 & 11.5 & 28.8 \\
\hline 36 & 2219.138 & 15 & 6.2 & 28.8 \\
\hline 40 & 2219.138 & 15 & 6.2 & 28.8 \\
\hline 44 & 2256.909 & 15 & 6.3 & 28.8 \\
\hline 48 & 2295 & 15 & 6.4 & 28.8 \\
\hline 52 & 2295 & 15 & 6.4 & 28.8 \\
\hline 56 & 2295 & 15 & 6.4 & 28.8 \\
\hline 60 & 2295 & 15 & 6.4 & 28.8 \\
\hline
\end{tabular}

Table-5Euro code design stresses and deflections for different floor heights of building for basic wind speed of $50 \mathrm{~m} / \mathrm{s}$

\begin{tabular}{|l|l|l|l|l|l|l|l|l|l|l|l|}
\hline Height & $\mathrm{t}$ & $\mathrm{P}_{\text {design }}$ & $\mathrm{f}_{\mathrm{g}, \mathrm{d}}$ & $\mathrm{F}_{\mathrm{d}}$ & $\mathrm{k}_{1}$ & $\mathrm{k}_{2}$ & $\sigma_{\max }$ & $\sigma_{\text {eff }}$ & $\mathrm{k}_{4}$ & $\mathrm{~F}_{\mathrm{d}}$ & $\mathrm{W}_{\max }$ \\
\hline $\mathrm{m}$ & $\mathrm{mm}$ & $\mathrm{N} / \mathrm{m}^{2}$ & $\mathrm{~N} / \mathrm{mm}^{2}$ & $\mathrm{~N} / \mathrm{m}^{2}$ & & & $\mathrm{~N} / \mathrm{mm}^{2}$ & $\mathrm{~N} / \mathrm{mm}^{2}$ & & $\mathrm{~N} / \mathrm{m}^{2}$ & $\mathrm{~mm}$ \\
\hline up to 8 & 8 & 2811 & 49.4 & 4217 & 0.372 & 0.322 & 55.2 & 47.7 & 0.085 & 2811 & 34 \\
\hline 12 & 8 & 2919 & 49.4 & 4379 & 0.368 & 0.316 & 56.7 & 48.7 & 0.084 & 2919 & 35 \\
\hline 16 & 8 & 3086 & 49.4 & 4628 & 0.361 & 0.308 & 58.7 & 50.1 & 0.082 & 3086 & 36 \\
\hline 20 & 10 & 3199 & 49.4 & 4798 & 0.479 & 0.427 & 51.7 & 46.1 & 0.109 & 3199 & 25 \\
\hline 24 & 10 & 3256 & 49.4 & 4884 & 0.477 & 0.425 & 52.4 & 46.7 & 0.108 & 3256 & 25 \\
\hline 28 & 10 & 3314 & 49.4 & 4971 & 0.473 & 0.422 & 52.9 & 47.2 & 0.106 & 3314 & 25 \\
\hline 32 & 10 & 3491 & 49.4 & 5236 & 0.465 & 0.415 & 54.8 & 48.9 & 0.105 & 3491 & 27 \\
\hline 36 & 10 & 3551 & 49.4 & 5326 & 0.462 & 0.413 & 55.4 & 49.5 & 0.105 & 3551 & 27 \\
\hline 40 & 10 & 3551 & 49.4 & 5326 & 0.462 & 0.413 & 55.4 & 49.5 & 0.105 & 3551 & 27 \\
\hline 44 & 10 & 3611 & 49.4 & 5417 & 0.459 & 0.41 & 55.9 & 50.0 & 0.105 & 3611 & 27 \\
\hline 48 & 10 & 3672 & 49.4 & 5508 & 0.457 & 0.408 & 56.6 & 50.6 & 0.105 & 3672 & 28 \\
\hline 52 & 10 & 3672 & 49.4 & 5508 & 0.457 & 0.408 & 56.6 & 50.6 & 0.105 & 3672 & 28 \\
\hline 56 & 10 & 3672 & 49.4 & 5508 & 0.457 & 0.408 & 56.6 & 50.6 & 0.105 & 3672 & 28 \\
\hline 60 & 10 & 3672 & 49.4 & 5508 & 0.457 & 0.408 & 56.6 & 50.6 & 0.105 & 3672 & 28 \\
\hline
\end{tabular}

Table-6 Euro code design stresses and deflections for different floor heights of building for Hud-Hud cyclone wind speed of $62.5 \mathrm{~m} / \mathrm{s}$

\begin{tabular}{|l|l|l|l|l|l|l|l|l|l|l|l|}
\hline Height & $\mathrm{t}$ & $\mathrm{P}_{\text {design }}$ & $\mathrm{f}_{\mathrm{g}, \mathrm{d}}$ & $\mathrm{F}_{\mathrm{d}}$ & $\mathrm{k}_{1}$ & $\mathrm{k}_{2}$ & $\sigma$ max & $\sigma$ eff & $\mathrm{k}_{4}$ & $\mathrm{~F}_{\mathrm{d}}$ & $\mathrm{w}_{\max }$ \\
\hline $\mathrm{m}$ & $\mathrm{mm}$ & $\mathrm{N} / \mathrm{m}^{2}$ & $\mathrm{~N} / \mathrm{mm}^{2}$ & $\mathrm{~N} / \mathrm{m}^{2}$ & & & $\mathrm{~N} / \mathrm{mm} 2$ & $\mathrm{~N} / \mathrm{mm} 2$ & & $\mathrm{~N} / \mathrm{m} 2$ & $\mathrm{~mm}$ \\
\hline up to 8 & 12 & 4393 & 49.4 & 6589 & 0.543 & 0.481 & 55.9 & 49.5 & 0.117 & 4393 & 22 \\
\hline 12 & 12 & 4562 & 49.4 & 6843 & 0.537 & 0.477 & 57.4 & 51.0 & 0.116 & 4562 & 22 \\
\hline 16 & 12 & 4821 & 49.4 & 7232 & 0.529 & 0.47 & 59.8 & 53.1 & 0.116 & 4821 & 23 \\
\hline 20 & 12 & 4998 & 49.4 & 7497 & 0.524 & 0.465 & 61.4 & 54.5 & 0.115 & 4998 & 24 \\
\hline 24 & 12 & 5088 & 49.4 & 7631 & 0.521 & 0.463 & 62.1 & 55.2 & 0.115 & 5088 & 24 \\
\hline 28 & 12 & 5178 & 49.4 & 7767 & 0.518 & 0.46 & 62.9 & 55.8 & 0.114 & 5178 & 25 \\
\hline 32 & 12 & 5454 & 49.4 & 8181 & 0.509 & 0.453 & 65.1 & 57.9 & 0.113 & 5454 & 26 \\
\hline 36 & 15 & 5548 & 49.4 & 8322 & 0.614 & 0.54 & 51.1 & 44.9 & 0.124 & 5548 & 15 \\
\hline 40 & 15 & 5548 & 49.4 & 8322 & 0.614 & 0.54 & 51.1 & 44.9 & 0.124 & 5548 & 15 \\
\hline 44 & 15 & 5642 & 49.4 & 8463 & 0.613 & 0.539 & 51.9 & 45.6 & 0.124 & 5642 & 15 \\
\hline 48 & 15 & 5738 & 49.4 & 8606 & 0.611 & 0.538 & 52.6 & 46.3 & 0.124 & 5738 & 15 \\
\hline 52 & 15 & 5738 & 49.4 & 8606 & 0.611 & 0.538 & 52.6 & 46.3 & 0.124 & 5738 & 15 \\
\hline 56 & 15 & 5738 & 49.4 & 8606 & 0.611 & 0.538 & 52.6 & 46.3 & 0.124 & 5738 & 15 \\
\hline 60 & 15 & 5738 & 49.4 & 8606 & 0.611 & 0.538 & 52.6 & 46.3 & 0.124 & 5738 & 15 \\
\hline
\end{tabular}

